\title{
Cathepsin B-Like Activity as a Serum Tumour Marker in Ovarian Carcinoma
}

\author{
Maria Warwas ${ }^{1}$, Halina Haczyńska ${ }^{1}$, Jerzy Gerber ${ }^{2}$ and Marek Nowak ${ }^{2}$ \\ 1 Department of Pharmaceutical Biochemistry, Wrocław University of Medicine, Wrocław, Poland \\ ${ }^{2}$ Clinic of Gynaecology, Wrocław University of Medicine, Wrocław, Poland
}

Summary: Serum cathepsin B-like activity was determined in 75 patients with ovarian carcinomas and in control groups. Ovarian cancers were of FIGO stages I-IV. Control groups consisted of 15 healthy women, 20 patients with myomas of the uterus, and 17 with benign ovarian cysts. Preoperative results showed elevated cathepsin Blike activity in $100 \%$ of the patients with ovarian cancers in relation to healthy subjects and patients with myomas, and in $78 \%$ in relation to benign ovarian cysts. Cathepsin B activity increased progressively with the FIGO stage of the disease, but the differences among particular stages were not statistically significant. In serous tumours cathepsin activity was significantly higher only in comparison to endometrioid ones $(p<0.001)$. Antipapain capacity of cystatins in the sera was also determined. No significant correlation between cathepsin B-like, and antipapain activity of cystatins was found. Serum cathepsin B-like activity may be helpful in the preoperative differential diagnosis between ovarian carcinomas and benign ovarian or uterine tumours.

\section{Introduction}

Epithelial ovarian cancer, which is the major cause of death among women with gynaecologic malignancies, produces no readily identifiable or measurable substances that might be useful in the early detection or management of the disease. These are imperative for effective treatment (1).

In an attempt to promote earlier diagnosis and improve monitoring of ovarian cancer, numerous markers have been studied $(2-6)$. To date, none has been found suitable for widespread clinical application.

Pietras et al. (7) have suggested that a cysteine peptidase, cathepsin $B^{1}$ ), is a sensitive marker for ovarian cancer diagnosis and may be of value in monitoring the course of the disease. These conclusions, based on small number of patients, seemed interesting enough to be verified.

Lysosomal cathepsin B, and its extracellularly secreted as well as plasma membrane-associated forms for which the name cathepsin B-like is often used, received great interest regarding their role(s) in biochemical processes underlying tumour growth, invasiveness, and metastasis (8).

The aim of the present study was to examine cathepsin B-like activity in sera of patients with ovarian cancer under aspects of diagnostic value of the enzyme. More-

\footnotetext{
1) Enzyme:

Cathepsin B (EC 3.4.22.1); papain (EC 3.4.22.2)
}

over, we wanted to find out if there is any correlation (dependence?) between cathepsin B, and its specific inhibitors - cystatins.

\section{Materials and Methods}

\section{Patients}

Patients attending the Clinic of Obstetrics and Gynaecology, Wrocław University of Medicine, in 1989-1994 were the subject of this study. The group with malignant tumours of the ovaries included

Tab. 1 Classification of ovarian cancers according to histopathological types and FIGO stages.

\begin{tabular}{lcccrrrr}
\hline \multirow{2}{*}{ Histological types } & \multicolumn{3}{l}{ Disease stage } & \multicolumn{2}{l}{ Total $\%$} \\
\cline { 2 - 5 } & I & II & III & IV & & \\
\hline Serous & 4 & 3 & 4 & 12 & 23 & 30.7 \\
Mucinous & 2 & - & - & 5 & 7 & 9.3 \\
Endometrioid & 2 & 3 & 3 & 14 & 22 & 29.3 \\
Undifferentiated & 2 & 1 & 2 & 7 & 12 & 16.0 \\
Clear cell & - & - & 3 & 3 & 6 & 8.0 \\
Other & - & 2 & - & 3 & 5 & 6.7 \\
Total & 10 & 9 & 12 & 44 & 75 & 100 \\
\hline
\end{tabular}

75 cases (tab. 1). The control groups consisted of 20 uterine myomas, and 17 benign ovarian cysts (cystis simplex, cystadenoma, cystis dermoidalis, cystis picea, cystis serosa, cystadenoma mucinosum). The age at diagnosis was in the group of cancers 1482 (median 51 a) in the myomas, and cysts 35-60 (median 48a), respectively. In all the patients with ovarian or uterine tumours laparotomy was performed. Ovarian tumour mass was removed and the extent of the disease stage according to the FIGO classification (9) was undertaken. Blood was taken before surgery from patients suspected of having ovarian cancer. The blood samples were centrifuged and the serum stored at $-20^{\circ} \mathrm{C}$ until use (up to 2 months). 
Tab. 2 Preoperative serum cathepsin B-like and antipapain capacity of cystatin levels in patients and controls.

\begin{tabular}{|c|c|c|c|c|c|}
\hline \multirow[t]{2}{*}{ Groups } & \multirow[t]{2}{*}{$\mathrm{N}$} & \multicolumn{2}{|l|}{ Cathepsin B } & \multicolumn{2}{|c|}{ Antipapain capacity of cystatins } \\
\hline & & $(\mathrm{mU} / \mathrm{l})$ & Range & $(\mathrm{mU} / \mathrm{l})$ & Range \\
\hline Healthy women & 15 & $4.00 \pm 3.47$ & $0.00-9.5$ & $72.51 \pm 7.09$ & $61.17-82.58$ \\
\hline Myomas of uterus & 20 & $10.82 \pm 6.12$ & $0.00-21.00$ & $80.17 \pm 15.27$ & $61.17-107.00$ \\
\hline Benign ovarian cysts & 17 & $40.00 \pm 31.15^{\#}$ & $5.00-97.32$ & $87.17 \pm 15.37^{\#}$ & $56.28-110.72$ \\
\hline \multicolumn{6}{|l|}{ Ovarian carcinoma } \\
\hline Stage I-IV & 75 & $194.54 \pm 161.53 *$ & $25.30-880.40$ & $99.93 \pm 25.32^{\#}$ & $30.58-174.35$ \\
\hline Stage I & 10 & $114.20 \pm 40.30^{*}$ & $68.50-203.50$ & $106.77 \pm 25.14^{*}$ & $67.29-145.29$ \\
\hline Stage II & 9 & $146.60 \pm 58.24^{*}$ & $25.30-200.10$ & $107.90 \pm 27.57^{\#}$ & $74.51-162.11$ \\
\hline Stage III & 12 & $157.07 \pm 72.77 *$ & $46.65-268.10$ & $96.22 \pm 17.37^{\#}$ & $72.61-137.95$ \\
\hline Stage IV & 44 & $232.82 \pm 196.74 *$ & $34.80-880.40$ & $97.49 \pm 26.08^{\#}$ & $30.58-156.00$ \\
\hline
\end{tabular}

* Significantly different from: healthy control, myomas of the uterus, and benign ovarian cysts (for cathepsin B-like activity $\mathrm{p}<0.001$, for inhibitory capacity $\mathrm{p}<0.01$ ).

The healthy control group, consisting of 15 healthy women at the ages of 28-46 (median 39a), was obtained from the Silesian Center "Dolmed" in Wrocław.

\section{Methods}

Cathepsin B-like activity in diluted $(1: 10)$ serum was performed with the procedure described by Szego et al. (10) in $40 \mathrm{mmol} / 1$ mixed sodium citrate/sodium phosphate buffer, $\mathrm{pH} 5.7$ in the presence of $5 \mathrm{mmol} / 1$ dithiothreitol and $0.17 \mathrm{mmol} / 1$ substrate (carbobenzoxy-Ala-Arg-Arg-4-methoxy- $\beta$-naphthylamide) in a total volume of $2 \mathrm{ml}$. After a $30 \mathrm{~min}$ incubation at $37^{\circ} \mathrm{C}$ the reaction was stopped by addition $0.5 \mathrm{ml}$ of $0.1 \mathrm{~mol} / 1 \mathrm{HCl}$. Fluorescence of the reaction product was measured at the emission peak of $410 \mathrm{~nm}$ on a Perkin-Elmer Fluorimeter LS-3 B with an activation beam of 292 $\mathrm{nm}$. Fluorescence readings were standardized with 4-methoxy- $\beta$ naphthylamine. The results were expressed in $\mathrm{mU} / \mathrm{l}$ (one $\mathrm{mU}$ of activity was defined as the amount of enzyme releasing $1 \mathrm{nmol}$ of 4-methoxy- $\beta$-naphthylamine per minute).

Antipapain activity of cystatine was measured after methylamine inactivation of $\alpha_{2}$-macroglobulin, as described by Minakata et al. (11), using caseine as a substrate and in the presence of $6 \mathrm{mmol} / \mathrm{l}$ cysteine (12). Papain purchased from Calbiochem, USA, was titrated with E-64 ( $L$-epoxysuccinyl-leucylamido(4-guanidino)butane) to determine the active concentration of the enzyme (13). One inhibitory unit was defined as the amount which inhibited $1 \mu \mathrm{mol}$ of active papain completely. This was determined by extrapolating the titration curves to zero papain activity.

As the upper normal limit (cut-off) of measured analytes we took ovarian cysts mean value plus two standard deviations (SD). Statistical analysis was performed using analysis of variance and the unpaired Student's t-test. Linear regressions were computed using the Pearson least-square method.

\section{Results}

Table 2 summarizes results of cathepsin B-like and antipapain activity of cystatin determinations in controls and patient groups. Table 3 presents the percentage of the results with value elevated above the cut-off values. Such a limit value was calculated from the mean plus two standard deviations measured in sera of patients with benign ovarian cysts. In healthy women the serum cathepsin activity ranged from 0.0 to $9.5 \mathrm{mU} / 1$, in the myoma patients from 0.0 to $21.0 \mathrm{mU} / \mathrm{l}$, and in the benign
\# Significantly different from: healthy control, and myomas of the uterus (for cathepsin B-like activity $p<0.001$, for inhibitory capacity $\mathrm{p}<0.01)$.

Tab. 3 Incidence of elevated cathepsin B-like activity and antipapain activity of cystatins in sera of patients with benign and malignant tumours.

Cut-off values are calculated from the results for the benign ovarian cyst group $(\overline{\mathrm{x}}+2 \mathrm{SD})$.

\begin{tabular}{lll} 
Groups & \multicolumn{2}{c}{ Cases with values above cut-off (\%) } \\
\cline { 2 - 3 } & $\begin{array}{l}\text { Cathepsin B } \\
102.3 \mathrm{mU} / 1\end{array}$ & $\begin{array}{l}\text { Antipapain capacity } \\
\text { of cystatins } \\
117.91 \mathrm{mU} / 1\end{array}$ \\
\hline Healthy women & 0.0 & 0.0 \\
Myomas of uterus & 0.0 & 0.0 \\
Benign ovarian cysts & 0.0 & 0.0 \\
Ovarian carcinoma & & \\
Stage I-IV & 78.6 & 22.6 \\
Stage I & 60.0 & 50.0 \\
Stage II & 77.7 & 22.0 \\
Stage III & 75.0 & 8.3 \\
Stage IV & 84.0 & 22.7 \\
\hline
\end{tabular}

ovarian cysts 5.0 to $97.0 \mathrm{mU} / \mathrm{l}$. The mean value of cathepsin activity in malignant tumours was significantly higher than in all the control groups examined $(\mathrm{p}<0.001)$. A wide dispersion of enzyme activity was observed. Range of serum concentrations found for ovarian cancer patients $(25.3-880.4 \mathrm{mU} / 1)$ showed considerable overlap with those found for benign ovarian cysts patients. Serum levels of cathepsin B-like activity in malignant tumours appear to increase progressively with the stage of the disease. However, because of high standard deviations, differences among groups were not statistically significant. The incidence of elevated cathepsin B-like activity concentrations above the cut-off value $(102.3 \mathrm{mU} / \mathrm{l})$ was $60 \%$ in patients at stage $\mathrm{I}$, and $84 \%$ at stage IV of the disease.

Analysis of the cathepsin B-like activity data in relation to histological cancer types showed significantly higher 
activity in patients with serous tumours in comparison to endometrioid types $(p<0.001)$ (data not shown).

Antipapain activity of cystatins was significantly raised in the group of benign and malignant ovarian tumors as compared with the healthy control group (tab. 2). The incidence of concentrations elevated above the cut-off value $(117.9 \mathrm{mU} / \mathrm{l})$ in the ovarian cancer groups ranged from 8 (stage III) to $50 \%$ (stage I). Increase of antipapain capacity was similar in all the histopathological cancer types represented in the present study (data not shown). A correlation coefficient equal to 0.2 between serum cathepsin B-like, and antipapain activity of cystatins was found.

\section{Discussion}

Though serum markers are of limited value in screening the general population for ovarian cancer, they can be used to assist the general gynaecologist in avoiding potentially difficult oncologic surgery. Therefore, it is important that discrimination between benign and malignant disease is made. Cathepsin B overexpression is common to many malignant tumours (14). Elevated serum activity or concentration was observed in patients with breast (15), colorectal (16), gastric (17), laryngeal (18), liver (19), and gynaecological $(7,20,21)$ carcinomas.

We examined the usefulness of measuring serum cathep$\sin$ B-like activity in the preoperative discrimination of ovarian carcinoma from benign tumours, and in the assessment of the extent of the disease. Our study showed elevated cathepsin B-like activity in $100 \%$ of the patients with malignant ovarian tumours in relation to healthy women and those with myomas of the uterus, and in $84 \%$ in relation to benign ovarian cysts. Pietras et al. (7) demonstrated marked elevation in cathepsin Blike activity in sera of patients with ovarian cancer of FIGO stage III $(+2490 \%)$ and IV $(+3890 \%)$.

We also examined patients with stage I and II. The level of cathepsin B-like activity in patients with stage I $(+1130 \%)$ and II $(+1320 \%)$ was lower as related to stage IV $(+2190 \%)$. The results were expressed as percent of elevation in relation to levels of enzyme activity in women with myomas. When benign ovarian cysts were used as a control the elevation was four times lower. Benitez-Bribesca et al. (21) reported a significant increase $(p<0.001)$ of cathepsin B activity in serum and vaginal fluid of all patients with carcinoma of the cervix uteri including that with stage 0 (carcinoma in situ) in comparison to healthy women. In contrast, $\mathrm{Ma}$ karewicz et al. (20) who used a control group consisting of patients with dysplasia have not found a rise of cathepsin B-like activity in early disease limited to the cervix uteri, while in early cervical carcinoma with metastases to pelvic lymph nodes the activity was markedly increased. Serum levels of the enzyme appear to increase parallel to the activity in tumour tissue. Tissue cytosol cathepsin B-like activity might also appear as a useful independent prognostic marker for survival in human cancers including ovarian ones $(14,22)$. According to the present study the sensitivity value of cathepsin Blike serum level calculated using the benign ovarian cysts group as a negative control is the same (64\%) in ovarian cancer as in cervical cancer, as described by Makarewicz et al. (20). It is not known whether the elevated activity of cathepsin B in serum is due only to its elevated production either to secretion by tumour tissue or to a disorder of its elimination from circulation or to a derangement of its specific inhibitors $(7,19,21)$.

Kininogens and cystatin $C$, together with $\alpha_{2}$-macroglobulin, are believed to be the most potent extracellular inhibitors of lysosomal cysteine peptidases as well as papain, a model plant protease (23).

Alterations in the balance between endogenous cysteine peptidase inhibitors, and cysteine peptidases have been postulated to contribute to malignant progression (21, 23). This was why we explored a possible correlation between serum cathepsin B-like activity and antipapain capacity of cystatins which is mainly due to kininogens (24). We measured the antipapain capacity after inactivation of $\alpha_{2}$-macroglobulin with methylamine. The inhibitory capacity was elevated in $36 \%$ of patients with ovarian cancer, which is consistent with our earlier observation (25). In spite of the low correlation coefficient between cathepsin B-like and antipapain activity the ratio of cathepsin activity to inhibitory activity rose from 0.08 in patients with myomas to 1.46 in patients with ovarian cancer of FIGO stage IV.

It is concluded that the serum cathepsin B-like activity determinations are helpful in the preoperative differential diagnosis between ovarian carcinomas and benign ovarian or uterine tumours.

\section{References}

1. Mutch DG, Williams S. Biology of epithelial ovarian cancer. Clin Obstet Gynecol 1994; 37:406-22.

2. Pearson VAH. Screening for ovarian cancer: a review. Public Health 1994; 108:367-82.
3. Devine PL, McGuckin MA, Quin RJ, Ward BG. Predictive value of the combination of serum markers, CA 125, CASA and TPS in ovarian cancer. Int J Gynecol Cancer 1995; $5: 170-8$. 
4. Medl M, Ogris E, Peters-Engl C, Leodolter S. TATI (tumourassociated trypsin inhibitor) as a marker of ovarian cancer. $\mathrm{Br}$ J Cancer 1995; 71:1051-4.

5. Sliutz G, Tempfer C, Kainz Ch, Mustafa G, Gitsch G, Koelbi $\mathrm{H}$, et al. Tissue polypeptide specific antigen and cancer associated serum antigen in the follow-up of ovarian cancer. Anticancer Res 1995; 15:1127-30.

6. Nagele F, Petru E, Medl M, Kainz Ch, Graf AH, Sevelda P. Preoperative CA 125: an independent prognostic factor in patients with stage I epithelial ovarian cancer. Obstet Gynecol $1995 ; 86: 259-64$.

7. Pietras RJ, Szego CM, Mangan CE, Seeler BJ, Burtnett MM. Elevated serum cathepsin B1-like activity in women with neoplastic disease. Gynecol Oncol 1979; 7:1-17.

8. Sloane BF, Moin K, Krepela E, Rozhin J. Cathepsin B and its endogenous inhibitors: the role in tumor malignancy. Cancer Metastasis Rev 1990; 9:333-52.

9. Averette HE, Donato DM. Ovarian carcinoma. Advances in diagnosis, staging and treatment. Cancer 1990; 65:703-8.

10. Szego CM, Seeler BJ, Smith RE. Lysosomal cathepsin B1: partial characterization in rat preputial gland and recompartmentation in response to estradiol-17 $\beta$. Eur J Biochem 1976; 69:463-74.

11. Minakata K, Asano M, Sato T, Harada N. Asay of $\alpha$-cysteine proteinase inhibitor in serum or plasma. Z Physiol Chem Hoppe-Seyler 1982; 363:493-8.

12. Sasaki M, Minakata K, Yamamoto H, Niwa M, Kato T, Ito N. A new component which specifically inhibits thiol proteinases. Biochem Biophys Res Commun 1977; 76:917-24.

13. Barrett AJ, Kembhavi AA, Brown MA, Kirschke H, Knight $\mathrm{CG}$, Tamai $\mathrm{M}$, et al. L-trans-Epoxysuccinyl-leucylamido (4guanidino)butane (E-64) and its analogues as inhibitors of cysteine proteinases including cathepsin $\mathrm{B}, \mathrm{H}$ and $\mathrm{L}$. Biochem $\mathrm{J}$ 1982; 201:189-98.

14. Schwartz MK. Tissue cathepsin as tumor markers. Clin Chim Acta $1995 ; 237: 67-78$.

15. Gabrijelcic D, Annan-Prah A, Skrk J, Kramberger M, Sebek S, Turk V. Determination of cathepsin B and $H$ in sera and tissues of breast cancer patients. Period Biol 1990; 92:154-5.

16. Dufek V, Jirasek V, Kral V, Matous B, Drazna E. Changes in serum cathepsin B-like activity in patients with colorectal cancer. Neoplasma 1985; 32:51-4.
17. Hirano T, Manabe T, Takenchi S, Immura M. Serum cathepsin B levels and tissue cathepsin B content in the patients with gastrointestinal malignancies. Med Sci Res 1993; 21:343-44.

18. Krcicki T, Siewiński M. Setum cathepsin B-like activity as a potential marker of laryngeal carcinoma. Eur Arch Otorhinolaryngol 1992; 249:293-5.

19. Dufek V, Matous B, Kral V. Serum alkaline-stable acid thiol proteinase - a possible marker for primary liver carcinoma. Neoplasma 1984; 31:99-107.

20. Makarewicz R, Drewa G, Szymański W, Skonieczna-Makarewicz I. Cathepsin B in predicting the extent of the cervix carcinoma. Neoplasma 1995; 42:21-4.

21. Benitez-Bribiesca L, De La Huerta-Sanchez R, Villaneueva C, Freyre-Horta R, Pastrana L, Guevara R. Proteinase and antiproteinase balance in patients with carcinoma of the uterine cervix before and after radiotherapy. Archiv Invest Med (Mexico) $1989 ; 20: 9-21$.

22. Kozyreva EA, Zhordaniia KI, Bassalyk LS, Vasiliev AV. Proteolytic lysosomal enzymes in ovarian cancer. Vopr Med Khim 1991; 37:20-30.

23. Calkins C, Sloane BF. Mammalian cysteine protease inhibitors: biochemical properties and possible roles in tumor progression. Biol Chem Hoppe-Seyler 1995; 376:71-80.

24. Assfalg-Machleidt I, Jochum M, Klaubert W, Inthorn D, Machleidt W. Enzymatically active cathepsin B dissociating from its inhibitor complexes is elevated in blood plasma of patients with septic shock and some malignant tumors. Biol Chem Hoppe-Seyler 1988; 369:263-9.

25. Warwas M, Gerber J, Pietkiewicz A. Haptoglobin and proteinase inhibitors in the blood serum of women with inflammatory, benign and neoplastic lesions of the ovary. Neoplasma 1986; $33: 79-84$.

\section{Received Febrary 27/October 15, 1996}

Corresponding author: Prof. Dr. Maria Warwas, Department of Pharmaceutical Biochemistry, Wrocław University of Medicine, ul. Szewska 38, PL-50-139 Wrocław, Poland 